\title{
Effects of dietary proteinase inhibitors from field bean (Vicia faba L.) and field-bean meal on pancreatic function in the rat
}

\author{
By BENE W. ABBEY, G. NORTON AND R. J. NEALE \\ Department of Applied Biochemistry and Nutrition, \\ University of Nottingham School of Agriculture, \\ Sutton Bonington, Loughborough LE $125 R$
}

(Received 12 April 1978 - Accepted 30 May 1978)

\begin{abstract}
I. Male weanling rats were fed casein diets containing $\mathrm{I} \cdot 25,2.5,5.0$ and $10 \mathrm{~g} / \mathrm{kg}$ active or autoclaved proteinase inhibitors (PI) from field bean (Vicia faba L.), and raw- and autoclaved-field-bean meal (FBM) diets. After 7, I4 and $2 \mathrm{I} d$ on the diets pancreas weights were measured and pancreas and intestinal trypsin $(E C$ 3.4.4.4) and chymotrypsin (EC 3.4.4.5) assayed.

2. Pancreas weights increased on the raw FBM and active-PI-supplemented diets. Maximum pancreatic hypertrophy measured as the percentage increase above controls was observed after $\mathrm{I} 4 \mathrm{~d}$ in rats fed on raw FBM. The same percentage increase in pancreas size compared with appropriate controls was obtained with rats fed casein diets supplemented with $5 \mathrm{~g}$ active $\mathrm{PI} / \mathrm{kg}$.

3. Pancreas trypsin and chymotrypsin levels decreased with increasing dietary PI level. Similarly, lower pancreas trypsin and chymotrypsin levels were observed in rats given raw FBM.

4. Intestinal trypsin and chymotrypsin increased with increasing dietary PI inclusion level. Although the magnitude of this response decreased with the period of feeding the differences in enzyme levels were still significant even after $2 \mathrm{I}$ d.

5. It was concluded that the PI alone in raw-FBM diets could not entirely be responsible for the enlargement of the pancreas and the excess secretion of pancreatic enzymes since in synthetic diets PI levels of five times those in FBM were required to produce responses of similar magnitude.
\end{abstract}

Chernick et al. (1948) reported that chicks fed raw soya-bean meal developed pancreatic hypertrophy which was associated with abnormally high levels of pancreatic proteases. This observation has since been confirmed not only for chicks (Garlick \& Nesheim, 1966; Hewitt et al. 1973) but also for rats (Kakade et al. 1973). It has also been well established that dietary trypsin inhibitors evoke an increased pancreatic enzyme secretion in rats and chicks (Lyman \& Lepkovsky, 1957; Khayambashi \& Lyman, 1966; Green \& Lyman, 1972).

Proteinase inhibitors (PI) isolated from field beans (Vicia faba L.) and included in the diets of rats have recently been shown to be physiologically active and it was suggested that these inhibitors were in part responsible for the growth depression observed when raw-field-bean meal (FBM) diets were fed to rats (Abbey et al. 1979). The purpose of the present work was to determine whether the feeding of raw FBM or PI extracted from raw FBM to rats elicited pancreatic hypertrophy. Further if pancreatic hypertrophy was induced whether it could be attributed entirely to the PI in the FBM. Finally it was hoped that by following the effect of PI on the levels of pancreatic enzymes in both the pancreas and intestine an insight into the general mode of action of PI in the animal could be obtained.

\section{MATERIALS AND METHODS}

The level of intestinal trypsin and chymotrypsin [EC 3.4.4.5] released when rats were given casein diets was initially determined to ascertain suitable dietary inclusion levels of PI. A technique of trained feeding (Lyman \& Lepkovsky, 1957) was used to maximize 
Table I. Small intestinal trypsin (EC 3.4.4.4) ([Tu] $)^{\text {cas* }} / \mathrm{kg}$ body-weight) and chymotrypsin $(\mathrm{EC} 3 \cdot 4 \cdot 4 \cdot 5)\left([\mathrm{Cu}]^{\text {cas }} \dagger / \mathrm{kg}\right.$ body-weight $)$ in rats $\mathrm{O}, \mathrm{I}$ and $2 \mathrm{~h}$ after feeding a basal casein diet $\ddagger$

(Mean values with their standard errors for five rats)

\begin{tabular}{|c|c|c|c|c|c|c|}
\hline & & & Period a & ng & & \\
\hline & & & & & & \\
\hline & Mean & SE & Mean & SE & Mean & SE \\
\hline Trypsin & 176 & 29 & 185 & 15 & 207 & 27 \\
\hline Chymotrypsin & 102 & I4 & II 8 & 4 & II 8 & 9 \\
\hline
\end{tabular}

* Anti-trypsin activity units with casein as substrate defined according to Kunitz (1947).

+ Anti-chymotrypsin.

$\ddagger$ Abbey et al. (1979).

enzyme secretion over a short period after the main meal. A basal casein diet (3-5 g) similar to that described in Abbey et al. (1979) was fed over a $3 \mathrm{~h}$ period each day to weanling male Wistar rats housed individually over a total period of $14 \mathrm{~d}$. This feeding time has been shown by Lyman \& Lepkovsky (1957) to be the minimum period required to maintain weight stability. On day 14 of the training period, the rats were given their usual daily meal and then killed with chloroform immediately and after $\mathrm{I}$ and $2 \mathrm{~h}$.

Immediately after the rats were killed the small intestine was separated from the mesentery and removed by excising at the duodenal and ileo-caecal junctions. The contents of the small intestine were washed out with approximately $40 \mathrm{ml}$ ice-cold saline $(8.5 \mathrm{~g}$ sodium chloride/l). The washings were homogenized and the homogenate centrifuged at $17500 \mathrm{~g}$ for $20 \mathrm{~min}$ at $4^{\circ}$. The supernatant fraction was decanted and the pellet resuspended in $5 \mathrm{ml}$ saline solution and after centrifugation the two supernatant fractions were combined and the volume adjusted to $50 \mathrm{ml}$ with saline solution.

The trypsin and chymotrypsin levels of the small intestine after $2 \mathrm{~h}$ are shown in Table $\mathrm{I}$. From this information the dietary level of PI which when consumed in a single meal would inhibit completely the intestinal trypsin and chymotrypsin released within $2 \mathrm{~h}$ of feeding was calculated to be $\mathrm{I} 0 \mathrm{~g} \mathrm{PI} / \mathrm{kg}$ diet.

Dietary levels of PI lower than those required for complete inhibition of intestinal trypsin and chymotrypsin were chosen because raw FBM contains only approximately $2 \mathrm{~g} \mathrm{PI} / \mathrm{kg}$. The basal diet was supplemented with PI either active or autoclaved (control) with corresponding reductions in the starch levels at levels $(\mathrm{g} / \mathrm{kg})$ of $\mathrm{I} \cdot 25(\operatorname{diet} \mathrm{A}), 2.5(\operatorname{diet} \mathrm{B}), 5.0$ (diet C) and Io (diet D). A raw FBM diet containing $120 \mathrm{~g}$ protein $/ \mathrm{kg} \operatorname{diet}($ nitrogen $\times 6.25$ ) was also fed and compared with an autoclaved FBM diet. Details of the experimental procedures, dietary composition and period of feeding have been described previously (Abbey et al. 1979). On days 6, 13 and 20 food was withheld from the rats overnight but reintroduced the next morning for a period of $3 \mathrm{~h}$. After a further $2 \mathrm{~h}$ fast the rat were killed and the small intestine removed. The pancreas was cooled to $0^{\circ}$ in ice-cold distilled water, freed of fat, blotted dry, weighed and stored in sealed aluminium containers at $-15^{\circ}$ until required.

\section{Pancreatic enzymes}

Pancreatic trypsinogen and chymotrypsinogen were isolated according to the method of Howard \& Yudkin (1963). Trypsinogen was activated by enterokinase (EC 3.4.21.9) $(20 \mathrm{mg} / \mathrm{ml}$ in $0.05 \mathrm{M}$-phosphate buffer, $\mathrm{pH} \mathrm{6.3)}$, which was prepared by the method of Hawk et al. (1954). Chymotrypsinogen was activated by pure hog trypsin $(40 \mu \mathrm{g} / \mathrm{ml}$ at pH 8.1). 
Table 2. Effects of proteinase inhibitors (PI) from field beans (Vicia faba $L$.) included in casein diets and autoclaved and raw field-bean meal (FBM) on the pancreas weights of rats ( $\mathrm{g} / \mathrm{kg}$ body-weight $)$

(Mean values with their standard errors for six rats)

\begin{tabular}{|c|c|c|c|c|c|c|}
\hline \multirow[b]{3}{*}{$\operatorname{Diet} \uparrow$} & \multicolumn{6}{|c|}{ Period on diet (d) } \\
\hline & \multicolumn{2}{|c|}{7} & \multicolumn{2}{|c|}{14} & \multicolumn{2}{|c|}{$2 \mathrm{I}$} \\
\hline & Mean & SE & Mean & SE & Mean & SE \\
\hline $\begin{array}{l}\mathbf{A} \\
\mathbf{A A}\end{array}$ & $\begin{array}{l}6 \cdot 42 \\
6 \cdot 60\end{array}$ & $\begin{array}{l}0.01 \\
0.01\end{array}$ & $\begin{array}{l}6 \cdot 54 \\
6 \cdot 54\end{array}$ & $\begin{array}{l}0.12 \\
0.34\end{array}$ & $\begin{array}{l}6 \cdot 23 \\
6.59\end{array}$ & $\begin{array}{l}0.12 \\
0.16\end{array}$ \\
\hline $\begin{array}{l}\text { B } \\
\text { BA }\end{array}$ & $\begin{array}{l}6 \cdot 94 \\
6 \cdot 72\end{array}$ & $\begin{array}{l}0.06 \\
0.01\end{array}$ & $\begin{array}{l}6.73 \\
6.05\end{array}$ & $\begin{array}{l}0.12 * \\
0.01\end{array}$ & $\begin{array}{l}6.48 \\
6.55\end{array}$ & $\begin{array}{l}0.14 \\
0.10\end{array}$ \\
\hline $\begin{array}{l}\mathrm{C} \\
\mathrm{CA}\end{array}$ & $\begin{array}{l}8.35 \\
6.47\end{array}$ & $\begin{array}{l}0.40^{*} \\
0.01\end{array}$ & $\begin{array}{l}7.49 \\
5.63\end{array}$ & $\begin{array}{l}0.54^{*} \\
0.01\end{array}$ & $\begin{array}{l}7 \cdot 07 \\
6 \cdot 15\end{array}$ & $\begin{array}{l}0.06^{*} \\
0.17\end{array}$ \\
\hline $\begin{array}{l}\mathrm{D} \\
\mathrm{DA}\end{array}$ & $\begin{array}{l}8 \cdot 17 \\
6 \cdot 26\end{array}$ & $\begin{array}{l}0.17^{*} \\
0.14\end{array}$ & $\begin{array}{l}7 \cdot 79 \\
5 \cdot 92\end{array}$ & $\begin{array}{l}0.17^{*} \\
0.10\end{array}$ & $\begin{array}{l}6 \cdot 97 \\
6 \cdot 05\end{array}$ & $\begin{array}{l}0.01 * \\
0.12\end{array}$ \\
\hline $\begin{array}{l}\text { Raw FBM } \\
\text { Autoclaved FBM }\end{array}$ & $\begin{array}{l}6 \cdot 85 \\
5 \cdot 82\end{array}$ & $\begin{array}{l}0.23^{*} \\
0.01\end{array}$ & $\begin{array}{l}7 \cdot 90 \\
5 \cdot 75\end{array}$ & $\begin{array}{l}0.50^{*} \\
0.08\end{array}$ & $\begin{array}{l}7 \cdot 36 \\
5 \cdot 76\end{array}$ & $\begin{array}{l}0.10^{*} \\
0.01\end{array}$ \\
\hline
\end{tabular}

* Significant difference from control value $(P<0.05)$.

$\dagger$ For details see Abbey et al. (1979). A, I.25 g PI/kg; B, 2.5 g PI/kg; C, 5 g PI/kg; D, Io g PI/kg. AA, BA, CA and DA autoclaved PI included at same levels as in diets A, B, C and D respectively.

\section{Assay of pancreatic and intestinal enzymes}

Intestinal and pancreatic extracts were assayed for trypsin using the method of Kunitz (1947) and chymotrypsin using the method of Kakade et al. (1970). Enzyme activities in the pancreas and small intestine were presented as units of enzyme activity per kg body-weight.

The results were subjected to analysis of variance and values at $P<0.05$ were considered significant.

\section{RESULTS}

\section{Pancreas weight}

At the end of $7 \mathrm{~d}$ the pancreas weights of rats fed on diets containing active PI (diets C, D and raw-FBM diet) were significantly higher than those given autoclaved PI (diets CA, DA and autoclaved-FBM diet) at the same level (Table 2). After $2 \mathrm{I}$ d, however, the pancreas weights of rats fed on diets $C$ and $D$ were reduced but were still significantly higher than rats fed on the autoclaved control diets. Increasing the active PI content of the casein diet from $\mathrm{I} \cdot 25$ to $5 \mathrm{~g} / \mathrm{kg}$ resulted in a significant increase in pancreatic hypertrophy but further increases in PI did not elicit a further increase in pancreas weight. Rats fed on diets containing autoclaved PI did not exhibit significant changes in pancreas weight at any inclusion level. The pancreas weights of rats fed on raw FBM were significantly greater $(P<0.00 \mathrm{I})$ than those of the control rats receiving autoclaved FBM at all periods, the increase on control values being $\mathrm{I} 8,37$ and $28 \%$ at $7, \mathrm{I} 4$ and $2 \mathrm{I} \mathrm{d}$ respectively. The maximum increase in pancreas enlargement, expressed as percentage of control values, occurred after i $4 \mathrm{~d}$ on these diets. A similar proportional increase in pancreas weight was observed when rats were fed on casein diets at $5 \mathrm{~g}$ PI $/ \mathrm{kg}$ inclusion levels. Pancreas weights on autoclaved FBM diets, however, were generally lower than those of rats on control casein diets. 
Table 3. Effect of dietary level of proteinase inhibitors (PI) from field beans (Vicia faba $L$.) and field-bean meal (FBM) on the level of trypsin (EC 3.4.4.4) activity in the pancreas of rat $\left([T u]^{\text {cas }}+/ \mathrm{kg}\right.$ body-weight $)$

(Mean values with their standard errors for six rats)

\begin{tabular}{|c|c|c|c|c|c|c|}
\hline \multirow[b]{3}{*}{ Diet $f$} & \multicolumn{6}{|c|}{ Period on diet (d) } \\
\hline & \multicolumn{2}{|c|}{7} & \multicolumn{2}{|c|}{ I4 } & \multicolumn{2}{|c|}{21} \\
\hline & Mean & SE & Mean & SE & Mean & SE \\
\hline $\begin{array}{l}\text { A } \\
\text { AA }\end{array}$ & $\begin{array}{l}193 \\
201\end{array}$ & $\begin{array}{r}5 \\
42\end{array}$ & $\begin{array}{l}193 \\
202\end{array}$ & $\begin{array}{l}7 \\
3\end{array}$ & $\begin{array}{l}192 \\
193\end{array}$ & $\begin{array}{r}10 \\
6\end{array}$ \\
\hline $\begin{array}{l}\text { B } \\
\text { BA }\end{array}$ & $\begin{array}{l}\text { I } 68 \\
226\end{array}$ & $\begin{array}{l}13^{*} \\
13\end{array}$ & $\begin{array}{l}184 \\
220\end{array}$ & $\begin{array}{l}4^{*} \\
2\end{array}$ & $\begin{array}{l}215 \\
238\end{array}$ & $\begin{array}{l}16 \\
29\end{array}$ \\
\hline $\begin{array}{l}\mathrm{C} \\
\mathrm{CA}\end{array}$ & $\begin{array}{l}149 \\
229\end{array}$ & $\begin{array}{l}6^{*} \\
1\end{array}$ & $\begin{array}{l}156 \\
201\end{array}$ & $\begin{array}{l}12^{*} \\
15\end{array}$ & $\begin{array}{l}172 \\
188\end{array}$ & $\begin{array}{l}16 \\
25\end{array}$ \\
\hline $\begin{array}{l}\mathrm{D} \\
\mathrm{DA}\end{array}$ & $\begin{array}{l}123 \\
218\end{array}$ & $\begin{array}{l}2^{*} \\
9\end{array}$ & $\begin{array}{l}142 \\
197\end{array}$ & $\begin{array}{l}20^{*} \\
11\end{array}$ & $\begin{array}{l}16 I \\
198\end{array}$ & $\begin{array}{l}6^{*} \\
7\end{array}$ \\
\hline $\begin{array}{l}\text { Raw FBM } \\
\text { Autoclaved FBM }\end{array}$ & $\begin{array}{r}70 \\
144\end{array}$ & $\begin{array}{l}\text { I I* } \\
\text { I4 }\end{array}$ & $\begin{array}{r}81 \\
140\end{array}$ & $\begin{array}{l}7^{*} \\
12\end{array}$ & $\begin{array}{r}90 \\
139\end{array}$ & $\begin{array}{c}11^{*} \\
9\end{array}$ \\
\hline
\end{tabular}

* Significant difference from control value $(P<0.05)$.

$\uparrow$ For details see Abbey et al. (1979). A, I.25 g PI $/ \mathrm{kg}$; B, $2.5 \mathrm{~g} \mathrm{PI} / \mathrm{kg} ; \mathrm{C}, 5 \mathrm{~g} \mathrm{PI} / \mathrm{kg} ; \mathrm{D}, 10 \mathrm{~g} \mathrm{PI} / \mathrm{kg}$. AA, BA, CA and DA have autoclaved PI included at same levels as in diets A, B, C and D respectively.

$\ddagger$ Anti-trypsin activity units with casein as substrate, defined according to Kunitz (1947).

Table 4. Effect of dietary level of proteinase inhibitors $(P I)$ from field beans (Vicia faba $L$.) and field-bean meal (FBM) on the level of pancreatic chymotrypsin (EC 3.4.4.5) of rats ([Cu $]^{\text {cast }} / \mathrm{kg}$ body-weight $)$

(Mean values with their standard errors for six rats)

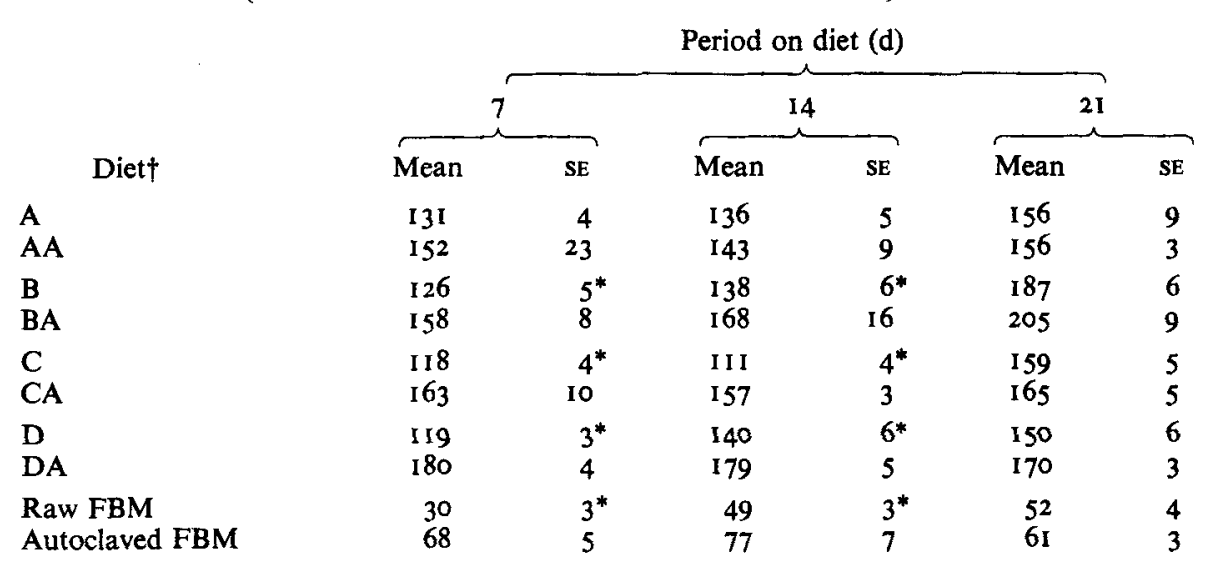

* Significant difference from control value $(P<0.05)$.

$\uparrow$ For details see Abbey et al. (1979). A, 1.25 g PI/kg; B, 2.5 g PI/kg; C, 5 g PI/kg; D, 10 g PI/kg. AA, BA, CA and DA have autoclaved PI included at same levels as in diets A, B, C and D respectively. $\ddagger$ Anti-chymotrypsin activity units with casein as substrate, defined according to Kunitz (I947). 
Table 5. Effect of dietary level of proteinase inhibitors (PI) from field bean (Vicia faba $L$.) and field-bean meal (FBM) on intestinal trypsin (EC 3.4.4.4) level of rats $\left([T u]^{\text {cas }} \ddagger / \mathrm{kg}\right.$ bodyweight)

(Mean values with their standard errors for six rats)

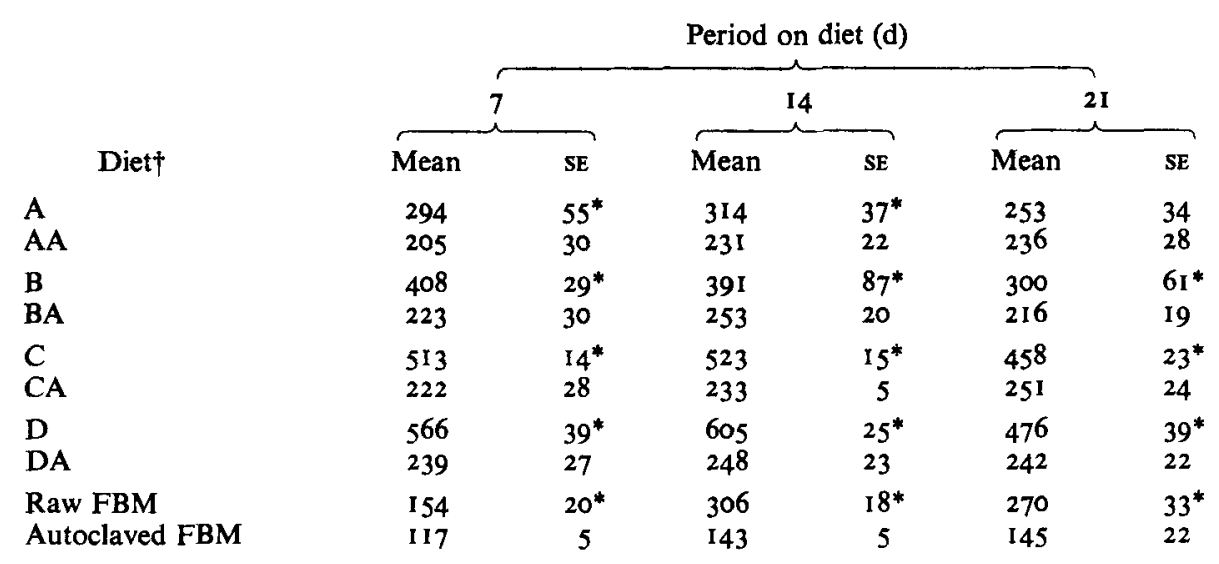

* Significant difference from control value $(P<0.05)$.

$\dagger$ For details see Abbey et al. (1979). A, I.25 g PI/kg; B, $2.5 \mathrm{~g} \mathrm{PI} / \mathrm{kg} ; \mathrm{C}, 5 \mathrm{~g} \mathrm{PI} / \mathrm{kg} ; \mathrm{D}$, $10 \mathrm{~g} \mathrm{PI} / \mathrm{kg}$. AA, $\mathrm{BA}, \mathrm{DA}$ and CA have autoclaved PI included at same levels as in diets A, B, C and D respectively.

$\ddagger$ Anti-trypsin activity units with casein as substrate, defined according to Kunitz (1947).

\section{Pancreas trypsin and chymotrypsin}

After $7 \mathrm{~d}$, pancreas trypsin level had decreased significantly $(P<0.00 \mathrm{I})$ with PI inclusion levels above $\mathrm{I} \cdot 25 \mathrm{~g} \mathrm{PI} / \mathrm{kg}$ (Table 3). Even at $\mathrm{I} \cdot 25 \mathrm{~g} \mathrm{PI} / \mathrm{kg}$ inclusion level pancreatic trypsin levels had decreased by $4 \%$ compared with the controls. At the $10 \mathrm{~g} \mathrm{PI} / \mathrm{kg}$ inclusion level the controls were reduced by $44 \%$. After I $4 \mathrm{~d}$ only the three highest PI inclusion levels (diets, B, C and D) elicited a significant decrease in pancreas trypsin level. After $2 \mathrm{I} d$ none of the PI-supplemented diets significantly reduced pancreas trypsin levels except diet D.

Pancreatic chymotrypsin levels (Table 4) as a result of feeding PI followed a similar pattern to that for trypsin although in all instances the absolute levels of the enzyme were lower than for trypsin. This reached a maximum at $14 \mathrm{~d}$ and decreased by $2 \mathrm{I} \mathrm{d}$.

Pancreatic trypsin levels in rats given raw FBM diets were also significantly reduced at the three different feeding periods. Pancreatic chymotrypsin levels in rats fed on raw FBM followed a similar pattern to those of trypsin although after 2 I d some adaptation had occurred.

\section{Intestinal trypsin and chymotrypsin}

In general the intestinal trypsin and chymotrypsin levels of rats fed on active PI-supplemented diets were significantly higher $(P<0.00 \mathrm{I})$ than the corresponding controls except on diet $\mathrm{A}$ after $2 \mathrm{I} \mathrm{d}$ (Table 5). After $7 \mathrm{~d}$ intestinal trypsin had increased by $43 \%$ on $\operatorname{diet} \mathrm{A}$ and $137 \%$ on diet D. By $2 \mathrm{I}$ d, however, a considerable reduction in intestinal trypsin level had taken place $(7 \%$ on diet A and $97 \%$ on diet D). The intestinal trypsin activity of the rats fed on raw FBM was significantly greater than rats fed on autoclaved FBM at all periods. This effect was more pronounced at $14 \mathrm{~d}$ (I $4 \%$ ) than at $2 \mathrm{I} \mathrm{d} \mathrm{(86 \% ).}$

The intestinal chymotrypsin level was higher in all rats fed on active-PI-supplemented diets (Table 6). After $7 \mathrm{~d}$ the intestinal chymotrypsin level was increased by $27 \%$ on diet A and by $142 \%$ on diet D. After $2 \mathrm{I}$ d, however, these values were only $20 \%$ and $68 \%$ on diets $A$ and $D$ respectively. Generally, the intestinal trypsin and chymotrypsin levels increased 
Table 6. Effect of dietary level of proteinase inhibitors (PI) from field bean (Vicia faba L.) and field-bean meal $(F B M)$ on the intestinal chymotrypsin $\left(\mathrm{EC}_{3} \cdot 4.4 \cdot 5\right)$ level of rats $\left([\mathrm{Cu}]^{\text {cas }}+1\right.$ $k g$ body-weight )

(Mean values with their standard errors for six rats)

\begin{tabular}{|c|c|c|c|c|c|c|}
\hline & & & Period & et (d) & & \\
\hline & & & & & & \\
\hline Diet $\uparrow$ & Mean & $\mathrm{SE}$ & Mean & SE & Mean & SE \\
\hline $\mathbf{A}$ & 234 & $5^{*}$ & 260 & $4^{*}$ & 278 & $10^{*}$ \\
\hline $\mathbf{A A}$ & I 84 & 10 & 190 & 34 & 232 & 5 \\
\hline B & 284 & $12 *$ & 341 & $35^{*}$ & 276 & $42^{*}$ \\
\hline $\mathbf{B A}$ & 185 & 30 & 222 & 17 & 201 & 36 \\
\hline $\mathrm{C}$ & 360 & $10^{*}$ & 430 & $17^{*}$ & 393 & $18^{*}$ \\
\hline CA & 179 & II & 202 & 20 & 225 & 16 \\
\hline $\mathbf{D}$ & 448 & $22^{*}$ & 408 & $12^{*}$ & 378 & $39^{*}$ \\
\hline DA & 185 & 10 & 189 & 25 & 225 & 12 \\
\hline Raw FBM & 158 & $15^{*}$ & 285 & $18^{*}$ & 248 & $2 *$ \\
\hline Autoclaved FBM & 120 & 4 & 130 & 4 & 136 & 9 \\
\hline
\end{tabular}

* Significant difference from control value $(P<0.05)$.

$\dagger$ For details see Abbey et al. (1979). A, I.25 g PI $/ \mathrm{kg}$; B, 2.5 g PI $/ \mathrm{kg} ; \mathrm{C}, 5 \mathrm{~g} \mathrm{PI} / \mathrm{kg}$; D, $10 \mathrm{~g} \mathrm{PI} / \mathrm{kg}$. AA, $\mathrm{BA}, \mathrm{CA}$ and DA have autoclaved PI included at same levels as in diets $\mathrm{A}, \mathrm{B}, \mathrm{C}$ and $\mathrm{D}$ respectively.

$\ddagger$ Anti-chymotrypsin activity units with casein as substrate, defined according to Kunitz (1947).

with increasing level of PI in the diet. The raw-FBM diets also elicited an increase in intestinal chymotrypsin level but the magnitude of this increase was much lower after $2 \mathrm{I} d$.

\section{DISCUSSION}

The results presented here demonstrate that PI consumption elicits physiological responses such as pancreatic hypertrophy, decreased pancreas levels of trypsin and chymotrypsin and increased intestinal levels of these enzymes. Although raw FBM elicited similar responses the PI inclusion levels to elicit responses in a casein-based diet were up to five times the normal endogenous levels found in field beans suggesting that factors other than PI are involved. Similar observations supporting these effects have been reported by Saxena et al. (1963), when chicks were fed semi-purified diets containing raw-soya-bean fractions devoid of the anti-trypsin activity for 7 and $9 \mathrm{~d}$. Chicks fed on diets containing the autoclaved fraction, however, had reduced pancreas size. Kakade et al. (1973) also reported similar effects when rats were fed for $20 \mathrm{~d}$ on diets containing soya-bean extracts. Removal of the PI did not reduce the size of the pancreas to the levels observed in rats on diets containing the heat-treated soya-bean extract, soya-bean flour or casein alone.

The hypertrophic response in our studies was observed as early as $7 \mathrm{~d}$. There was, however, some adaptation to the dietary PI since pancreatic hypertrophy was clearly reduced after $2 \mathrm{I} d$ except in rats on the raw-FBM diet. The rapidity of the response of the pancreas to PI from field beans in these studies supports the earlier work of Haines \& Lyman (I96I), who fed rats heated-soya-bean-meal diets supplemented with soya-bean trypsin inhibitor for 7, 14 and $2 \mathrm{I} \mathrm{d}$. Rackis (1965) also observed that in rats the maximum hypertrophy occurred $9 \mathrm{~d}$ after feeding raw soya-bean meal whereas in chicks, $2 \mathrm{l} d$ was necessary before maximum enlargement occurred after feeding raw soya-bean meal (Gertler \& Nitsan, 1970).

Field-bean PI when added to casein diets interfered with protein utilization in rats by reducing the protein efficiency ratio although no change in the apparent nitrogen digesti- 
bility was obtained (Abbey et al. 1979). The adverse effects of PI on protein utilization have been ascribed to the formation of stable enzyme-inhibitor complexes (Lepkovsky et al. I959; Seidl et al. 1969) which reduce protein digestion and as a consequence utilization.

After the ingestion of PI the rat secretes greater amounts of pancreatic enzymes into the intestine. It is well known that trypsin and chymotrypsin secretion is controlled by a feedback mechanism involving the level of intestinal trypsin and chymotrypsin (Green \& Lyman, 1972). In our experiments it is evident that dietary PI even at low levels stimulated an excess production of pancreatic enzymes. The normal feedback control proposed by Neiss et al. (1972) ceased to operate and intestinal levels of trypsin and chymotrypsin increased to well above the control levels. Neiss et al. (1972) suggested that soya-bean PI stimulated pancreatic hypertrophy and hypersecretion by causing the release of excess cholecystokinin-pancreozymin (CCK-PZ) from the duodenal mucosa. Rothman \& Wells (1967) showed that repeated subcutaneous injections of pancreozymin for $4 \mathrm{~d}$ resulted in pancreatic hypertrophy, stimulated pancreatic enzyme (trypsin, chymotrypsin and amylase) secretion and inhibited growth of rats. The possibility exists, therefore, that this hormone is closely involved with the physiological effect of PI in the diet.

The nutritional effects of PI are even more difficult to explain when more recent work on the stability of the PI to hydrolysis within the intestinal tract is taken into consideration. Abbey, Norton \& Neale (unpublished results) have shown that PI are rapidly degraded by protein hydrolases present in the small intestine of the rat despite the PI being unsusceptible to trypsin and chymotrypsin in the intestine. The tentative conclusion drawn from these results is that the amino acids of PI complexes, PI-trypsin, PI-chymotrypsin will be available to the rat since neither PI nor PI-enzyme complexes are excreted by the rat. The possibility still exists, however, that the refractive proteinase inhibitors are incompletely degraded in the small intestine and either converted into microbial proteins in the caecum or are excreted from the rat probably as ammonia gas or urea. This may explain why no difference was observed among the test diets and their controls when apparent $\mathrm{N}$ digestibility was measured.

In conclusion, it has been possible to demonstrate that the PI in raw FBM cannot be directly responsible for the magnitude of enlargement of the pancreas and the stimulation of the secretion of excess pancreas enzymes. Other factors must be present in the field beans either acting directly or synergistically with the PI to produce these effects.

\section{REFERENCES}

Abbey, B. W., Neale, R. J. \& Norton, G. (1979). Br. J. Nutr. 4I, 3 I.

Chernick, S. S., Lepkovsky, S. \& Chaikoff, I. L. (1948). Am. J. Physiol. 155, 33.

Garlick, J. D. \& Nesheim, M. C. (I966). J. Nutr. 88, 100.

Gertler, A. \& Nitsan, Z. (I970). J. Nutr. 24, 893.

Green, G. M. \& Lyman, R. L. (1972). Proc. Soc. exp. Biol. Med, 140, 6.

Haines, P. C. \& Lyman, R. L. (I96I). J. Nutr. 74, 445.

Hawk, P. B., Oser, B. L. \& Summerson, W. H. (1954). Practical Physiological Chemistry, 13 th ed. London: Churchill.

Hewitt, D., Coates, M. E., Kakade, M. L. \& Liener, I. E. (1973). Br. J. Nutr. 29, 423.

Howard, F. \& Yudkin, J. (1963). Br. J. Nutr. 17, 28I.

Kakade, M. L., Hoffa, D. E. \& Liener, I. E. (1973). J. Nutr. ro3, 1772.

Kakade, M. L., Swenson, D. H. \& Liener, I. E. (I970). Analyt. Biochem. 33, 255.

Khayambashi, H. \& Lyman, R. L. (1966). J. Nutr. 89, 455.

Kunitz, M. (1947). J. gen. Physiol. 30, 291.

Lepkovsky, S., Bingham, E. \& Pencharz, R. (1959). Poult. Sci. 38, 1289.

Lyman, R. L. \& Lepkovsky, S. (1957). J. Nutr. 62, 269.

Neiss, E., Ivy, C. A. \& Nesheim, M. (1972). Proc. Soc. exp. Biol. Med. 140, 291.

Rackis, J. J. (1965). Fedn Proc. Fedn Am. Socs exp. Biol. 24, 1488.

Rothman, S. \& Wells, H. (1967). Am. J. Physiol. 213, 215.

Saxena, H. C., Jensen, L. S. \& McGinnis, J. (1963). Proc. Soc. exp. Biol. Med. II2, Io1.

Seidl, D., Jaffe, M. \& Jaffe, W. G. (1969). J. agric. Fd Chem. 17, 13 I 8. 